\title{
LACCASE IMMOBILISATION ON MESOSTRUCTURED SILICAS
}

\author{
Jolanta Bryjak $^{* 1}$, Katarzyna Szymańska ${ }^{2}$, Andrzej B. Jarzębski ${ }^{2,3}$ \\ ${ }^{1}$ Wrocław University of Technology, Faculty of Chemistry, Department of Bioorganic Chemistry, \\ Norwida 4/6, 50-373 Wrocław, Poland \\ ${ }^{2}$ Department of Chemical Engineering, Silesian University of Technology, M. Strzody 7, \\ 44-100 Gliwice, Poland \\ ${ }^{3}$ Institute of Chemical Engineering, Polish Academy of Sciences, Battycka 5, 44-100 Gliwice, \\ Poland
}

\begin{abstract}
Extracellular laccase produced by the wood-rotting fungus Cerrena unicolor was immobilised covalently on the mesostructured siliceous foam (MCF) and three hexagonally ordered mesoporous silicas (SBA-15) with different pore sizes. The enzyme was attached covalently via glutaraldehyde (GLA) or by simple adsorption and additionally crosslinked with GLA. The experiments indicated that laccase bound by covalent attachment remains very active and stable. The best biocatalysts were MCF and SBA-15 with Si-F moieties on their surface. Thermal inactivation of immobilised and native laccase at $80^{\circ} \mathrm{C}$ showed a biphasic-type activity decay, that could be modelled with 3parameter isoenzyme model. It appeared that immobilisation did not significantly change the mechanism of activity loss but stabilised a fraction of a stable isoform. Examination of time needed for $90 \%$ initial activity loss revealed that immobilisation prolonged that time from 8 min (native enzyme) up to $155 \mathrm{~min}$ (SBA-15SF).
\end{abstract}

Keywords: Laccase, immobilisation; mesostructured enzyme carrier; thermal stability

\section{INTRODUCTION}

Oxidising enzymes such as laccases (EC 1.10.3.2) attract considerable attention because they offer unique solutions to selective oxidation reactions in aqueous, organic and biphasic systems that have been extensively reviewed (Burton, 2003, Duran et al., 2002; Witayakran and Ragauskas, 2009). These enzymes are of particular interest not only because they are easily available at scale, but because their copper-containing redox sites catalyse oxidation of important substrates with concomitant reduction of molecular oxygen to water, without expensive co-factors. As the array of substrates for laccases includes alkenes, phenolics, polyamines and lignin-related molecules, these enzymes can be used in bioremediation processes, as adjuvant in textile or paper industries, biosensing elements and also as catalysts in organic synthetic chemistry and in biotransformations of natural compounds (Burton, 2003; Duran et al., 2002; Mikolasch and Schauer, 2009; Witayakran and Ragauskas, 2009). However, operational stability of native enzymes is rather limited. Therefore, immobilisation is very often applied in order to ease this limitation. The main advantage of immobilised enzymes is their easy recovery from reaction mixture by simple filtration or application in continuous processes. The enzymes are usually attached to water or organic solvent insoluble carriers, and that can additionally improve both their thermal and operational stability. Amongst many immobilisation techniques, covalent binding and simple adsorption of laccases seem to be the most popular and effective methods (Duran et al., 2002).

*Corresponding author, e-mail: jolanta.bryjak@pwr.wroc.pl 
Typically, the selection of an immobilisation method suitable for a particular enzyme, is achieved by surveying a broad database of performances of different immobilised preparations. With this in mind we undertook a systematic study of Cerrena unicolor laccase immobilisation onto typical enzyme carriers: acrylic beads (Bryjak et al., 2007), cellulose-based carriers (Rekuć et al., 2008), commercial silica gels (Rekuć et al., 2010) and onto a relatively new class of carriers - silica mesoporous cellular foams (MCFs) (Rekuć et al., 2009) beads, all modified with various anchor groups, to find that only aminated MCFs could offer very active preparations. Mesoporous silicas reveal significant advantages as enzyme supports: i. particles are fairly small $(20-30 \mu \mathrm{m})$ with a very open structure of mesopores which and this relaxes considerable diffusional constrains; ii. pore sizes are even over $20 \mathrm{~nm}$, thus similar or larger than most enzyme molecules; iii. large internal surface area is easily accessible to enzymes; iv. high chemical, thermal, mechanical and biological resistance and environmental inertion (Avnir et al., 2006; Chaudhary et al., 2007; Hudson, et al. 2008; Pierre, 2004).

Although laccase covalently bound to MCFs carriers appeared to be extremely active, none of the preparations was stable enough at elevated temperatures. In fact, some were more stable than a native preparation, but the improvement was not deemed satisfactory. Therefore, the present research was focused on the covalent and adsorptive immobilisation of laccase onto aminated mesocellular materials, some of which were additionally modified with Si-F moieties. For this purpose MCF with ultra large mesopores was synthesised as well as three other ordered mesoporous silicas with hexagonal pore arrangement (SBA-15): a conventional SBA-15, SBA-15L with same mesopore structure as MCF, yet not using $\mathrm{NH}_{4} \mathrm{~F}$ during synthesis, SBA-15S and SBA-15SF were more conventional silicas with medium sized mesopores but differed in presence of $\mathrm{NH}_{4} \mathrm{~F}$ in synthetic protocol (SBA-15SF). The effect of carrier structure and additional crosslinking with glutaraldehyde on the activity and stability of immobilised enzyme was examined and after that, selected very active enzyme-carrier preparations were tested at elevated temperature. Special attention was given to thermal stability as it was the first sign that immobilised preparations could be sufficiently stable under process conditions.

\section{MATERIALS AND METHODS}

\subsection{Materials}

Trihydroxymethylaminomethane (tris), glutaraldehyde (GLA), 2,2'-azino-bis(3-ethylbenzothiazoline-6sulfonate) sodium salt (ABTS) were purchased from Sigma. Tetraethoxysilane (98\%, TEOS), 1,3,5trimethylbenzene (TMB), 1-chloro-2,3-epoxypropane, chloroacetic acid and 2-aminoethyl-3aminopropyltrimethoxysilane (AEAPTS) applied as donors of amine groups, were obtained from Aldrich. Pluronic PE 9400 was purchased from BASF. Other reagents, all of analytical grade, were supplied by POCh (Poland).

\subsection{Synthesis and functionalization of $S B A-15$ and MCF materials}

The synthesis of SBA-15L (with ultra large mesopores) was as described by Szymańska et al. (2009). In brief, $6 \mathrm{~g}$ Pluronic P123 was dissolved in $2 \mathrm{M} \mathrm{HCl}$ solution $\left(180 \mathrm{~cm}^{3}\right)$ at $40{ }^{\circ} \mathrm{C}$ (Lei $\mathrm{C}$ et al., 2006) and then $10.5 \mathrm{~cm}^{3}$ of TMB and $13.5 \mathrm{~cm}^{3}$ of TEOS were added and stirred for $12 \mathrm{~h}$ at the same temperature. The mixture was heated up to $40{ }^{\circ} \mathrm{C}$ for $8 \mathrm{~h}$ and next to $100{ }^{\circ} \mathrm{C}$ for $24 \mathrm{~h}$, without stirring. The white precipitate was collected by filtration, dried in air, and finally calcined at $550{ }^{\circ} \mathrm{C}$ for $6 \mathrm{~h}$. Preparation of SBA-15S and SBA-15SF (with medium size mesopores) was done as described Zhao et al. (1998). Pluronic P123 (4 g) was dissolved in $30 \mathrm{~cm}^{3}$ of water and $120 \mathrm{~cm}^{3}$ of $2 \mathrm{M} \mathrm{HCl}$ solution with stirring at $35{ }^{\circ} \mathrm{C}$ (in case of SBA-15SF $0.04 \mathrm{~g}$ of $\mathrm{NH}_{4} \mathrm{~F}$ was added). Then $9.1 \mathrm{~cm}^{3}$ of TEOS was added into that solution with stirring at this temperature for $20 \mathrm{~h}$. The mixture was aged at $80^{\circ} \mathrm{C}$ overnight without stirring. The solid product was recovered, washed, and air dried at room temperature. 
Calcination was carried out by increasing temperature from 23 to $500{ }^{\circ} \mathrm{C}$ for $8 \mathrm{~h}$ and heating at $500{ }^{\circ} \mathrm{C}$ for 6 h.

Preparation of MCF (with ultra large mesopores) was done as described by Szymańska et al. (2009). In a typical procedure Pluronic P123 (4 g) was dissolved in $1.6 \mathrm{M} \mathrm{HCl}\left(75 \mathrm{~cm}^{3}\right)$ at room temperature and then TMB $\left(5.8 \mathrm{~cm}^{3}\right)$ and $\mathrm{NH}_{4} \mathrm{~F}(0.023 \mathrm{~g})$ were added under vigorous stirring at $40{ }^{\circ} \mathrm{C}$. After $1 \mathrm{~h}$ stirring TEOS was added $\left(4.7 \mathrm{~cm}^{3}\right)$, stirred for $1 \mathrm{~h}$ and stored at $40{ }^{\circ} \mathrm{C}$ for $20 \mathrm{~h}$ and then at $100{ }^{\circ} \mathrm{C}$ for $24 \mathrm{~h}$. The precipitate was filtered, dried at room temperature for 4 days and calcined at $500{ }^{\circ} \mathrm{C}$ for $8 \mathrm{~h}$.

Amino groups were grafted onto pristine carriers surface by reacting suitable amounts of organosilanes (AEAPTS dissolved in toluene) under reflux $\left(24 \mathrm{~h}, 40^{\circ} \mathrm{C}\right)$ with silanols present on the silica surface to obtain a load of functional moiety of about $1.5 \mathrm{mmol} / \mathrm{g}$ of silica (Rekuć at al., 2009).

\subsection{Characterisation of MCF and SBA-15 materials}

The values of specific surface area $\left(S_{B E T}\right)$, pore volume $\left(V_{p N 2}\right)$, diameter of cells $(d p)$, and that of interconnected windows $(d w)$ of pristine (calcined) carriers were determined from the analysis of nitrogen adsorption/ desorption isotherms measured at $-196{ }^{\circ} \mathrm{C}$ using a Micromeritics ASAP 2000 instrument and applying BJH (Barret-Joyner-Halenda) method. Prior to measurements the samples were outgassed at $150{ }^{\circ} \mathrm{C}$ for $4 \mathrm{~h}$. The texture of materials was also examined using transmission electron microscopy (TEM, Tecnai G2 apparatus operating at $200 \mathrm{kV}$ ).

\subsection{Enzyme preparation and activity assays}

The wood-rotting fungus Cerrena unicolor (Bull.ex.Fr.) Murr, No 139, was obtained from the culture collection of the Department of Biochemistry, UMCS University (Lublin, Poland). Microorganism cultivation and laccase production was performed according to the method described by Al-Adhami et al. (2002). The laccase containing culture fluid was purified according to the procedure proposed by Bryjak and Rekuć (2010). The enzyme activity was determined from the change of optical density in time and calculated from the initial reaction rate region, using $0.207 \mathrm{mM}$ ABTS in $0.1 \mathrm{M}$ citratephosphate buffer, $p H$ 5.3, as a substrate (Childs and Bardsley, 1975). The enzyme activity unit (U) was defined as the amount of the enzyme required to change absorbance $(420 \mathrm{~nm})$ of 1.0 per min at $30^{\circ} \mathrm{C}$. The mean analytical error was less than $\pm 2.0 \%$.

Protein concentration was determined by the Lowry's method (Lowry at al., 1957) using bovine serum albumin as a standard. The mean analytical error was less than $\pm 2.5 \%$.

The activity of immobilised enzymes was measured in a well-mixed (200 rpm) reactor in batch regime. The immobilised enzyme was suspended in the buffer $(p H 5.3)$, placed into reactor the temperature of which was maintained at $30^{\circ} \mathrm{C}$. Then, preheated substrate in the buffer was added $(1.25 \mathrm{mM}$ end ABTS concentration) and several samples were taken from the reactor at one-minute intervals. After absorbance $(420 \mathrm{~nm})$ measurement the samples were returned to the reactor to ensure a constant ratio of carrier to substrate volume. Immobilised enzyme activity was recalculated per $1 \mathrm{~cm}^{3}$ of freely sedimented carrier. The mean analytical error was less than $\pm 4.5 \%$.

\subsection{Laccase immobilisation}

For immobilisation, the functionalised carrier $\left(4-5 \mathrm{~cm}^{3}\right)$ was washed by centrifugation with distilled water and $0.1 \mathrm{M}$ phosphate buffer $(p H 7)$ and then activated with $2.5 \%(\mathrm{v} / \mathrm{v})$ GLA for $2 \mathrm{~h}$. The same but not activated carriers were used for adsorptive immobilisation. All the carriers were suspended in $10 \mathrm{~cm}^{3}$ of laccase solution $(p H 7)$ and left at $4{ }^{\circ} \mathrm{C}$ overnight. After that the excess protein was removed 
by washing under different $p H$ and ionic strength of buffers. Next, all immobilised preparations were divided into two parts and one of them was additionally crosslinked with $2.5 \%(\mathrm{v} / \mathrm{v})$ GLA solution $(p H 7 ; 1 \mathrm{~h})$. Active aldehyde groups remaining on the carrier were blocked in $0.5 \mathrm{M}$ tris- $\mathrm{HCl}$ buffer, $p H$ 8.2. Finally, the obtained preparations were rinsed with $0.1 \mathrm{M}$ phosphate-citrate buffer of $p H 5.3$ and activities were measured. The immobilised preparations were stored at $4{ }^{\circ} \mathrm{C}$ in an appropriate buffer and they were washed several times with the buffer shortly prior to experiments. All the eluates were collected and analysed for the presence of protein and activity. The amount of bound protein (activity units) was calculated from a difference between the amount used for immobilisation and that washed off (protein/activity mass balance).

\subsection{Thermal inactivation of a native and immobilised enzyme}

Thermal inactivation was tested at $80{ }^{\circ} \mathrm{C}$ as the enzyme was previously found to be very stable at temperatures ranging from 18 up to $55^{\circ} \mathrm{C}$ (Bryjak et al., 2007). For the inactivation experiments a settled immobilised preparation $\left(0.1 \mathrm{~cm}^{3}\right)$ in the buffer was introduced into thin-layer probes and the excess of the buffer was removed. Then $2 \mathrm{~cm}^{3}$ of the buffer $\left(80^{\circ} \mathrm{C}\right)$ was added to the probes, tightly closed and placed into a water bath of $80^{\circ} \mathrm{C}$. At certain time intervals the samples were taken out, cooled rapidly in an iced-water bath and stored therein prior to activity measurement conducted after $1.5 \mathrm{~h}$ of storage. A control experiment was conducted using native enzyme of similar reactivity. Kinetic parameters of thermal inactivation model were estimated using nonlinear regression (parameter estimation software OriginPro 8).

\section{RESULTS AND DISCUSSION}

\subsection{Properties of the supports}

Table 1 lists the properties of surface structure of the pristine supports obtained from nitrogen adsorption experiments and Fig. 1 shows TEM images of the supports. The specific surface area (Table 1) was almost the same in all carriers, whereas the pore volume and pore diameter for MCF and SBA-15L were respectively, two and three times larger than those for SBA-15SF and SBA-15S. It can be seen that only SBA-15S and SBA-15SF showed an ordered (hexagonal) structure (Fig. 1). TEM studies confirmed a significant similarity in pore structure of both MCF and SBA-15L, that indeed, appeared to be much more open than that of SBA-15S or SBA-15SF and it was predominated by large spherical mesopores $(d p)$ connected by windows $(d w)$. A modification of pristine silica carriers with organosilanes resulted in a slight decrease of surface parameters (results not shown) but had little effect on pore sizes.

Table 1. Structure parameters of MCF and SBA carriers

\begin{tabular}{|c|c|c|c|c|}
\hline Carrier & $\begin{array}{c}S_{B E T} \\
{\left[\mathrm{~m}^{2} / \mathrm{g}\right]}\end{array}$ & $\begin{array}{c}V_{p N 2} \\
{\left[\mathrm{~cm}^{3} / \mathrm{g}\right]}\end{array}$ & $\begin{array}{c}d p \\
{[\mathrm{~nm}]}\end{array}$ & $\begin{array}{c}d w \\
{[\mathrm{~nm}]}\end{array}$ \\
\hline MCF & 620 & 2.50 & 27.0 & 14.0 \\
\hline SBA-15L & 635 & 2.16 & 25.2 & 10.7 \\
\hline SBA-15SF & 638 & 1.11 & 8.5 & - \\
\hline SBA-15S & 645 & 0.71 & 6.3 & - \\
\hline
\end{tabular}



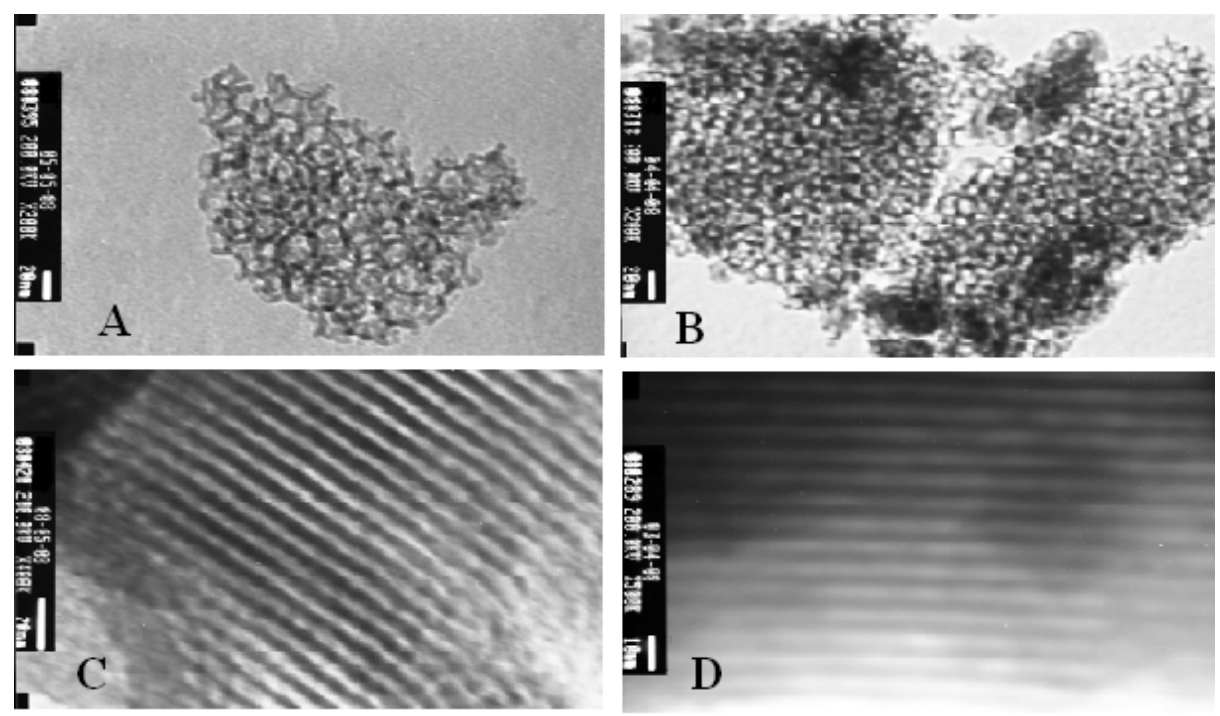

Fig. 1. TEM images for: MCF (A), SBA-15L (B), SBA-15SF (C) and SBA-15S (D)

\subsection{Laccase immobilisation}

It is clear that activity of a biocatalyst experimentally determined is the most important single parameter of an immobilised enzyme. Its value is strongly influenced by the amount of bound protein, enzyme affinity to a carrier surface and accessibility of the active center for substrates. In the case of adsorption (Table 2) very weak dependence of the protein content on the pore size was observed. Protein load varied from 0.615 to $0.775 \mathrm{mg} / \mathrm{cm}^{3}$ of the carriers and, that probably reflected similarity in their specific surface area. Interestingly, when laccase was covalently bound to the carriers, the protein content was about a half of that value. This phenomenon can be explained by a change in surfaceprotein interactions, caused by activation of amino groups with GLA, which reduced affinity of the enzyme molecules to the carriers' surface, and also concluded from the proportionally lower value of expected activity of covalently bound laccase. But, surprisingly enough, this significantly lower protein content and expected activity values resulted in actual (measured) catalysts activities even five-fold larger than those obtained for the enzyme bound by adsorption. This clearly demonstrates that the covalent bonding via amino groups with GLA activation is exceptionally effective for immobilisation of laccase. Moreover, closer examination shows that the observed phenomena are more complex. Two couples of aminated samples, respectively: SBA-15L and MCF or SBA-15S and SBA-15SF had a similar pore structure and laccase was immobilised on their surface in the same way. Yet, the activities of SBA-15L and SBA-15S were by ca. 14\% lower than those of MCF and SBA-15SF and this can hardly be explained by minor differences in porosities of the corresponding materials. As the sole difference lay in the synthesis of pristine MCF and SBA-15SF or SBA-15L and SBA-15S, respectively, and more specifically in that ammonium fluoride was applied in the synthesis of the former and not in the latter group, we may speculate that its presence changed the intrinsic properties of the silica surface in MCF and SBA-15SF materials, perhaps due to formation of small but strongly hydrophobic Si-F entities. Their presence could positively affect protein orientation on the biocatalysts surface to afford higher activity. It is noteworthy that the same trend was more recently observed also in the hydrolysis of sucrose using biocatalysts with invertase immobilised on identical silica carriers (Szymańska et al, 2009). This suggestion can be supported by activities of immobilised preparations in which the proteins were additionally crosslinked after their immobilisation (Fig. 2). In this case the activities of MCF and SBA-15SF catalysts were about $11 \%$ lower than those of SBA-15S and SBA-15L, respectively. As can be seen from Figure 2, an additional crosslinking of proteins already bound to the carriers by adsorption 
or covalent attachment brought about activity increase from 14 up to $33 \%$. It is likely, that it was caused by a reduction in desorption of laccase bound unspecifically.

Table 2. Activity of laccase immobilised on mesoporous silicas by adsorption and covalent attachment

\begin{tabular}{|c|c|c|c|c|c|c|}
\hline \multirow{2}{*}{ Carrier } & Method & $\begin{array}{c}\text { Bound } \\
\text { protein } \\
{\left[\mathrm{mg} / \mathrm{cm}^{3}\right]}\end{array}$ & $\begin{array}{c}\text { Expected } \\
\text { activity } \\
{\left[\mathrm{U} / \mathrm{cm}^{3}\right]}\end{array}$ & $\begin{array}{c}\text { Measured } \\
\text { activity } \\
{\left[\mathrm{U} / \mathrm{cm}^{3}\right]}\end{array}$ & $\begin{array}{c}\text { Active in } \\
\text { bound protein } \\
{[\%]}\end{array}$ & $\begin{array}{c}\text { Activity } \\
\text { Yield } \\
{[\%]}\end{array}$ \\
\hline \multirow{2}{*}{ MCF } & covalent & 0.248 & 4755 & 2599 & 54.7 & 28.8 \\
\cline { 2 - 7 } & adsorption & 0.774 & 6926 & 420 & 6.1 & 5.8 \\
\hline \multirow{2}{*}{ SBA-15L } & covalent & 0.297 & 3396 & 2250 & 66.3 & 25.9 \\
\cline { 2 - 7 } & adsorption & 0.615 & 6165 & 420 & 6.8 & 6.5 \\
\hline \multirow{2}{*}{ SBA-15SF } & covalent & 0.239 & 3346 & 2584 & 77.2 & 44.6 \\
\cline { 2 - 7 } & adsorption & 0.651 & 6140 & 450 & 7.3 & 7.2 \\
\hline \multirow{2}{*}{ SBA-15S } & covalent & 0.354 & 4737 & 2215 & 46.8 & 27.4 \\
\cline { 2 - 7 } & adsorption & 0.775 & 8118 & 495 & 6.1 & 5.5 \\
\hline
\end{tabular}

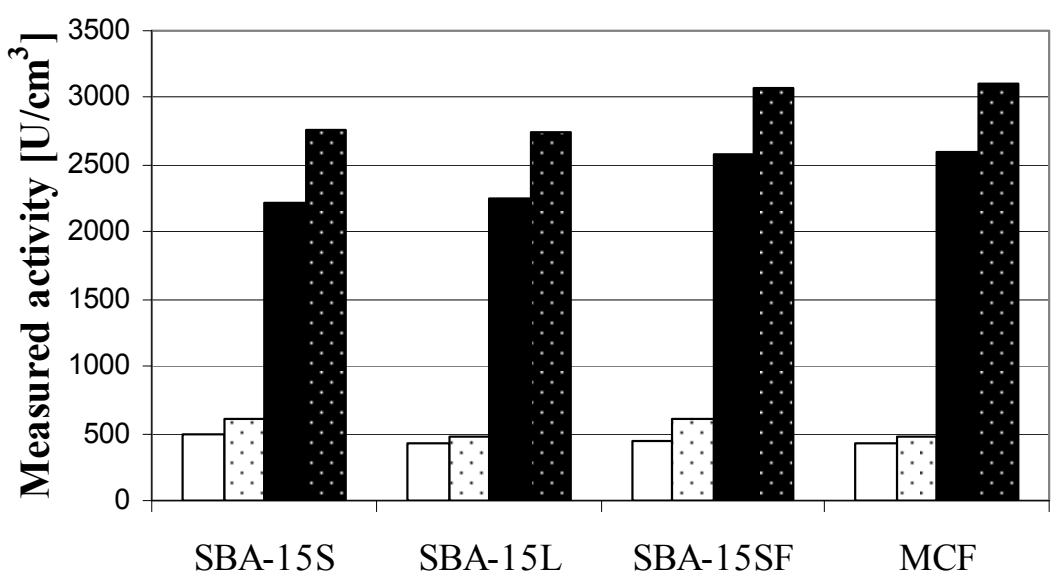

Fig. 2. Activities of laccase immobilised on different carriers: white bars - adsorption; black bars - covalent attachment; dotted bars - as the previous ones but additionally crosslinked with GLA

To summarise, it appears that biocatalysts obtained by adsorption of laccase on MCF and SBA-15 type of mesoporous silica are not very active. For that reason, thermal stability tests were performed only for the preparations with laccase attached by the covalent method.

\subsection{Thermal stability of immobilised laccase}

Temperature is a critical variable in enzyme reactor operation. It produces two contradictory effects; an increase in reaction rate, but also an increase in the rate of enzyme inactivation. Then, an experimental analysis of the inactivation process is a prerequisite to most applications of enzymes. Our previous study showed that thermal stability of laccase immobilised on MCF carrier, incubated at $80{ }^{\circ} \mathrm{C}$, was only marginally better than that of a free enzyme (Rekuć, 2009). To improve this stability by synthesis of new sol-gel carriers was the main objective of the present work. For this purpose all the preparations with the enzyme attached covalently with or without additional crosslinking were incubated at this 
temperature. A typical example of obtained results is presented in Figure 3. As can be seen from Figure $3 \mathrm{a}$, both the native and immobilised laccase inactivation patterns are quite similar and they feature a rapid activity loss in the first phase followed by its significantly slower decay in the second one, typical for a biphasic inactivation (see Fig. 3b). Interestingly, Michniewicz et al. (2006) reported before that laccase from Cerrena unicolor consists of 2 isoforms which differ in thermal stability. For that reason, a simple isoenzyme mechanism (Sadana, 1991) of inactivation was adopted:

$$
\begin{aligned}
& E_{1} \stackrel{k_{1}}{\longrightarrow} I_{1} \\
& E_{2} \stackrel{k_{2}}{\longrightarrow} I_{2}
\end{aligned}
$$

to obtain a final expression for activity:

$$
\frac{A}{A_{0}}=a \exp \left(-k_{1} t\right)+b \exp \left(-k_{2} t\right)
$$

where: $E_{1}$ and $E_{2}$ are native isoforms, $I_{1}$ and $I_{2}$ are inactive forms, $A$ and $A_{0}$ are activities at given time and at time $t=0, k_{1}$ and $k_{2}$ are the reaction rate constants, $a$ and $b$ are stable and labile fraction of isoenzymes, respectively.
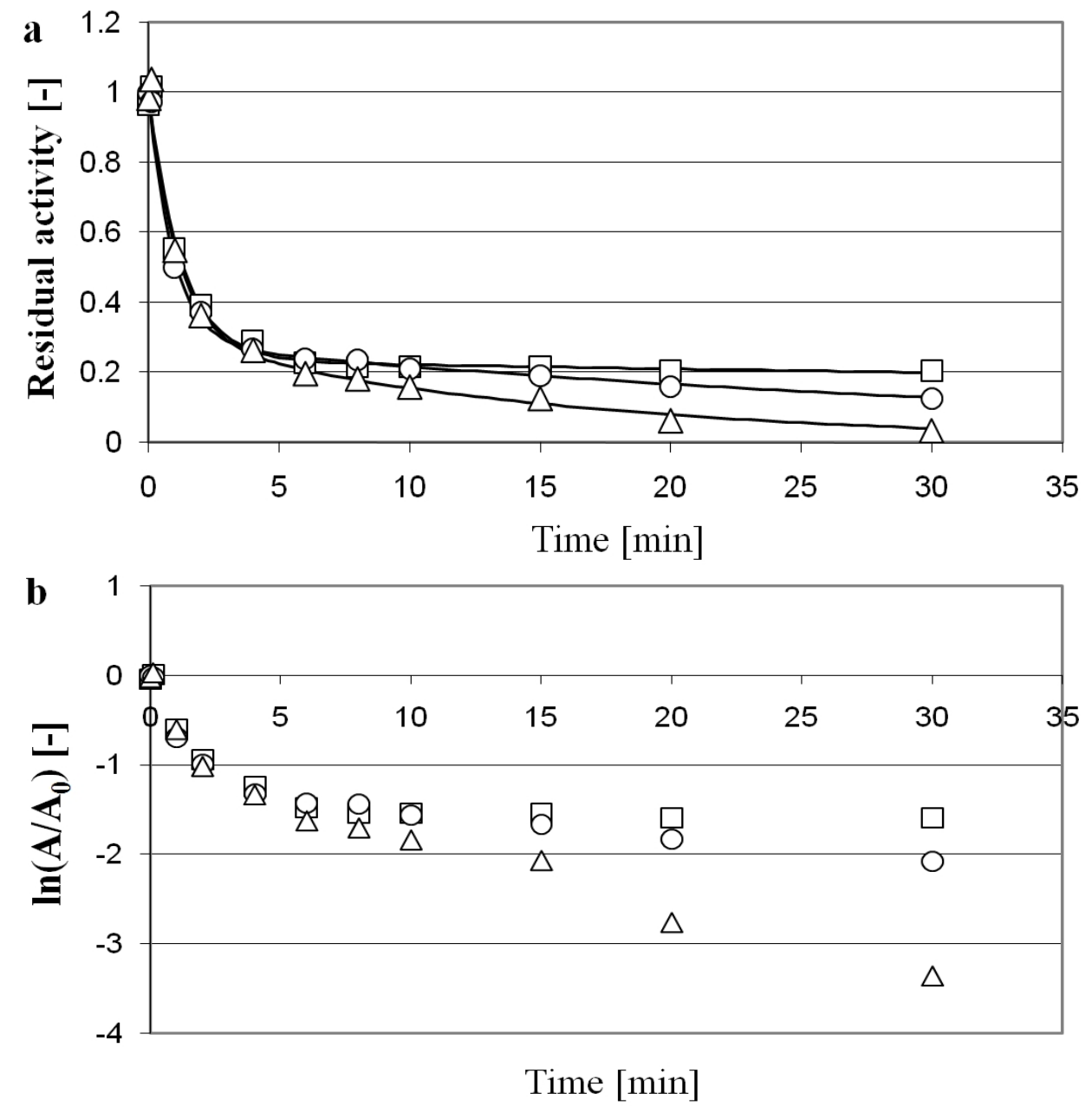

Fig. 3. Thermal inactivation of laccase at $80^{\circ} \mathrm{C}$. Symbols: yellow points - native enzyme; blue points - laccase immobilised on SBA-15SF; green points - laccase immobilised on the same carrier with additional crosslinking; lines display predictions from the isoenzyme model (2). b) $\ln \left(A / A_{0}\right)$ vs. heating time demonstration of the biphasic inactivation behaviour of the native and immobilised laccase 
When a sum of $a$ and $b$ fractions is normalised this equation can be simplified to a three parameter expression with $b=1-a$. From the values given in Table 3 it can be seen that the initial fraction of a stable form of the native enzyme was about $31 \%$ and it did not change notably after immobilisation. The values of $k_{l}$, corresponding to the stable fraction, showed a stabilisation of this isoform by immobilisation, except for MCF. However, the labile isoform was not stabilised (c.f. $k_{2}$ constants), except for SBA-15L without GLA crosslinking. Surprisingly, no evident positive stabilisation effect of post-immobilisation protein crosslinking was observed. To determine the type of silica and protein immobilisation method that afford most stable catalysts, we calculated the time needed for a $90 \%$ loss of the initial activity (Fig. 4). It can be seen that immobilised laccase was more stable than its native form, and among various mesoporous silica supports that of SBA-15SF appeared to give the most stable preparations. As it appeared earlier to be nearly as active as MCF, it is the best catalysts among the investigated mesoporous silica materials. But of considerable interest may also be quite a surprising observation that post-attachment protein crosslinking strongly destabilised the enzyme, probably by modification of aminoacid(s) involved in maintaining the enzyme's compact structure.

Table 3. Comparison of kinetic parameters of inactivation of the native and immobilised laccase at $80{ }^{\circ} \mathrm{C}$. Symbols: $k_{1}$ and $k_{2}$ - reaction rate constants for stable and labile fraction of isoenzymes, $a-$ fraction of stable isoenzyme

\begin{tabular}{|c|c|c|c|c|}
\hline Enzyme/Carrier & $\begin{array}{c}\text { Glutaraldehyde } \\
\text { crosslinking }\end{array}$ & $\begin{array}{c}a \\
{[-]}\end{array}$ & $\begin{array}{c}k_{l} \\
{[1 / \mathrm{min}]}\end{array}$ & $\begin{array}{c}k_{2} \\
{[1 / \mathrm{min}]}\end{array}$ \\
\hline \multirow{2}{*}{ Native } & - & $0.305 \pm 0.066$ & $0.0672 \pm 0.012$ & $0.92 \pm 0.155$ \\
\hline \multirow{2}{*}{ MCF } & No & $0.343 \pm 0.067$ & $0.083 \pm 0.020$ & $0.800 \pm 0.162$ \\
\cline { 2 - 5 } & Yes & $0.295 \pm 0.057$ & $0.065 \pm 0.020$ & $0.835 \pm 0.133$ \\
\hline \multirow{2}{*}{ SBA-15L } & No & $0.376 \pm 0.058$ & $0.018 \pm 0.06$ & $0.599 \pm 0.101$ \\
\cline { 2 - 5 } & Yes & $0.448 \pm 0.021$ & $0.045 \pm 0.005$ & $1.153 \pm 0.125$ \\
\hline \multirow{2}{*}{ SBA-15SF } & No & $0.234 \pm 0.022$ & $0.0054 \pm 0.0017$ & $0.784 \pm 0.088$ \\
\cline { 2 - 5 } & Yes & $0.284 \pm 0.021$ & $0.026 \pm 0.005$ & $1.153 \pm 0.125$ \\
\hline \multirow{2}{*}{ SBA-15S } & No & $0.320 \pm 0.021$ & $0.047 \pm 0.006$ & $1.068 \pm 0.093$ \\
\cline { 2 - 5 } & Yes & $0.318 \pm 0.034$ & $0.059 \pm 0.018$ & $0.768 \pm 0.099$ \\
\hline
\end{tabular}

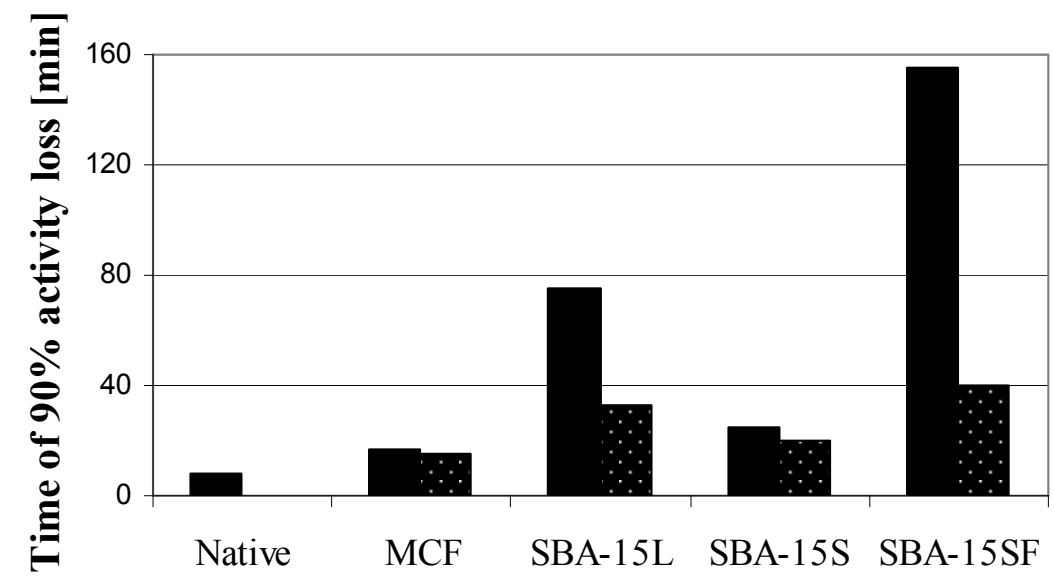

Fig. 4. Time needed for $90 \%$ activity loss of laccase incubated at $80^{\circ} \mathrm{C}$. Preparations with post-attachment crosslinking are marked by dotted bars 


\section{CONCLUSIONS}

Siliceous mesostructured materials (MCF and SBA-15) show a great potential as carriers for laccase immobilisation to provide very active biocatalysts. The final activity of preparations depends on their structure and the applied method of protein binding. Regardless of the type of silica carrier, the covalent attachment of the enzyme via glutaraldehyde appeared to be about five times more effective than the adsorption-based method. This observation contradicts a common view that harsh conditions of covalent immobilisation strongly denature enzymes' superstructure and significantly reduce their activity. It is also supported by the fact that the additional crosslinking of already immobilised laccase had no detrimental effect on the activity of the catalysts. The most active preparations were those immobilised covalently on MCF and SBA-15SF carriers and that can be linked with the presence of Si$\mathrm{F}$ moieties on the surface of these materials.

Thermal inactivation of covalently-bound laccase, performed at $80^{\circ} \mathrm{C}$, revealed that its activity decays in a biphasic way that can be modelled by a simple isoenzyme equation, typical for the native enzyme. It was found that immobilisation did not affect the fraction of a stable isoform, and except for MCFbased catalysts, it reduced the rate of its inactivation. The performed studies of a deep activity decay (up to $10 \%$ of the initial value) indicate that: i. post-attachment protein crosslinking destabilises the enzyme; ii. immobilisation of laccase onto MCFs appeared to be not effective at all; iii. immobilisation of laccase on SBA-15L and SBA-15SF carriers significantly prolonged the time of activity decay, from $8 \mathrm{~min}$ (for native enzyme) to 75 and $155 \mathrm{~min}$, respectively. Thus, taking into account the highest activity and thermal stability of the immobilised laccase, aminated and GLA activated SBA-SF emerges as the carrier of choice.

The support for this work by the Polish State Committee for Science and Research under grant N N209 119337, 2009-2012 is gratefully acknowledged.

\section{REFERENCES}

Al-Adhami A.A.J.H., Bryjak J., Greb-Markiewicz B., Peczyńska-Czoch W., 2002. Immobilization of woodrotting fungi laccases on modified cellulose and acrylic carriers. Process Biochem., 37, 1387-1394. DOI: 10.1016/S0032-9592(02)00023-7.

Avnir D., Coradin T., Lev O., Livage J., 2006. Recent bio-applications of sol-gel materials. J. Mater. Chem., 16, 1013-1030. DOI: 10.1039/b512706h.

Bryjak J., Kruczkiewicz P., Rekuć A., Peczyńska-Czoch W., 2007. Laccase immobilization on copolymer of butyl acrylate and ethylene glycol dimethacrylate. Biochem. Eng. J., 35: 325-332. DOI: 10.1016/j.bej.2007.01.031.

Bryjak J., Rekuć A., 2010. Effective purification of Cerrena unicolor laccase using microfiltration, ultrafiltration and acetone precipitation. Appl. Biochem. Biotechnol., 160, 2219-2235. DOI: 10.1007/s12010-009-8791-9.

Burton S.G., 2003. Laccases and phenol oxidases in organic synthesis - a review. Curr. Org. Chem., 7, 13171331.

Chaudhary Y.S., Manna S.K., Mazumdar S., Khushalani D., 2008. Protein encapsulation into mesoporous silica hosts. Micropor. Mesopor. Mat., 109, 535-541. DOI: 10.1016/j.micromeso.2007.06.001.

Childs R.E., Bardsley W.G., 1975. The steady-state kinetics of peroxidase with 2,20-azino-di-(3-ethylbenzthiazoline-6-sulphonic acid) as chromogen. Biochem. J., 145, 93-103.

Durán N., Rosa M.A., D’Annibale A., Gianfreda L., 2002. Applications of laccases and tyrosinases (phenoloxidases) immobilized on different supports: a review. Enzyme Microb. Technol., 31, 907-931. DOI: 10.1016/S0141-0229(02)00214-4.

Hudson S., Cooney J., Magner E., 2008. Proteins in mesoporous silicates. Angewandte Chemie. Int. Ed., 47, 8582-8594. 
Lei C., Shin Y., Magnusom J.K., Fryxell G., Lasure L.L., Elliott D.C., Liu J., Ackerman E.J., 2006. Characterization of functionalized nanoporous supports for protein confinement. Nanotechnol., 17, 5531-5538. DOI: $10.1088 / 0957-4484 / 17 / 22 / 001$.

Lowry O.H., Rosebrough N.J., Farr A.L., Randall R.J., 1951. Protein measurement with the Foulin phenol reagent. J. Biol. Chem., 193, 265-275.

Michniewicz A., Ullrich R., Ledakowicz S., Hofrichter M., 2006. The white-rot fungus Cerrena unicolor strain 137 produces two laccase isoforms with different physico-chemical and catalytic properties. Appl. Microbiol. Biotechnol., 69, 682-688. DOI: 10.1007/s00253-005-0015-9.

Mikolasch A., Schauer F., 2009. Fungal laccases as tools for the synthesis of new hybrid molecules and biomaterials. Appl. Microbiol. Biotechnol., 82, 605-624. DOI: 10.1007/s00253-009-1869-z.

Pierre A.C., 2004. The sol-gel encapsulation of enzymes. Biocatal. Biotransform., 22, 145-170. DOI: 10.1080/10242420412331283314.

Rekuć A., Kruczkiewicz P., Jastrzembska B., Liesiene J., Peczyńska-Czoch W., Bryjak J., 2008. Laccase immobilization on the tailored cellulose-based Granocel carriers. Int. J. Biol. Macromol., 42, 208-215. DOI: 10.1016/j.ijbiomac.2007.09.014.

Rekuć A., Bryjak J., Szymańska K., Jarzębski A.B., 2009. Laccase immobilization on mesostructured cellular foams affords preparations with ultra high activity. Proc. Biochem., 44, 191-198. DOI: 10.1016/j.procbio.2008.10.007.

Rekuć A., Bryjak J., Szymańska K., Jarzębski A.B., 2010. Very stable silica-gel-bound laccase biocatalysts for the selective oxidation in continuous systems. Biores. Technol., 101, 2076-2083. DOI: 10.1016/j.biortech.2009.11.077.

Sadana A., 1991. Biocatalysis. Fundamentals of enzyme deactivation kinetics. Prentice Hall, Englewood Cliffs, New Jersey.

Szymańska K., Bryjak J., Jarzębski A.B, 2009. Immobilization of invertase on mesoporous silicas to obtain hyper active biocatalysts. Top. Catal., 52, 1030-1036. DOI: 10.1007/s11244-009-9261-x.

Witayakran S., Ragauskas A.J., 2009. Synthetic applications of laccase in Green Chemistry. Adv. Synth. Catal., 351, 1187-1209. DOI: 10.1002/adsc.200800775.

Zhao D., Huo Q., Feng J., Chmelka B.F., Stucky G.D., 1998. Nonionic triblock and star diblock copolymer and oligomeric surfactant syntheses of highly ordered, hydrothermally stable, mesoporous silica structures. J. Am. Chem. Soc., 120, 6024-6036. DOI: 10.1021/ja974025i. 